Annals of Plant and Soil Research 23(1): 30-35(2021)

https://doi.org/10.47815/apsr.2021.10025

\title{
Yield, nutrient uptake and quality of wheat (Triticum aestivum) under nitrogen and sulphur nutrition in alluvial soil
}

\section{VINAY SINGH}

\begin{abstract}
Department of Agricultural Chemistry and Soil Science, Raja Balwant Singh College, Bichpuri, Agra (U.P.)283105
\end{abstract}

Received: November, 2020; Revised accepted: January, 2021

\begin{abstract}
A 2-year field experiment was conducted at Panwari village of Agra district (U.P.) during rabi season of 2015-16 and 2016-17 to study the response of wheat (Triticum aestivum L) to different levels of nitrogen and sulphur. Four levels each of nitrogen $\left(0,40,80\right.$ and $\left.120 \mathrm{~kg} \mathrm{ha}^{-1}\right)$ and sulphur $\left(0,10,20\right.$ and $\left.30 \mathrm{~kg} \mathrm{ha}^{-1}\right)$ were evaluated in randomized block design with three replications. The results revealed that the application of $120 \mathrm{~kg}$ $\mathrm{N} \mathrm{ha}{ }^{-1}$ recorded the significantly highest plant height $(92.1 \mathrm{~cm})$ and test weight $(40.9 \mathrm{~g})$. The highest yields of grain $\left(5.57 \mathrm{~h} \mathrm{ha}^{-1}\right)$ and straw $\left(6.86 \mathrm{~h} \mathrm{ha}^{-1}\right)$ were recorded with $120 \mathrm{~kg} \mathrm{~N} \mathrm{ha}^{-1}$ and the grain and straw yield increments were to the extent of 44.6 and $42.6 \%$, respectively. The sulphur level of $30 \mathrm{~kg} \mathrm{ha}^{-1}$ recorded the highest grain $\left(5.13 \mathrm{t} \mathrm{ha}^{-1}\right)$ and straw $\left(6.36 \mathrm{tha}^{-1}\right)$ yield being statistically at par with $20 \mathrm{~kg} \mathrm{~S}^{-1} \mathrm{ha}^{-1}$ but significantly higher than $10 \mathrm{~kg} \mathrm{~S} \mathrm{ha-1.} \mathrm{The} \mathrm{results} \mathrm{indicated} \mathrm{the} \mathrm{superiority} \mathrm{of} \mathrm{combined} \mathrm{use} \mathrm{of} N$ and $S$ in improving the productivity of wheat to compared to application of $N$ alone. The content and yield of protein were also increased with $\mathrm{N}$ application and maximum values were recorded with $120 \mathrm{~kg} \mathrm{~N} \mathrm{ha}{ }^{-1}$. There was a significant increase in protein content and yield of wheat grain and maximum values were recorded with $30 \mathrm{~kg} \mathrm{~S} \mathrm{ha-1.} \mathrm{A}$ phenomenal increase in $N, P$ and $S$ uptake by wheat grain and straw was recorded due to increasing levels of $N$ and $S$ up to $120 \mathrm{~kg}$ and $30 \mathrm{~kg} \mathrm{ha}^{-1}$, respectively. The available $N$ and $S$ reduced in the control plot in post harvest soil over their initial values. The higher values of available $N\left(222.5 \mathrm{~kg} \mathrm{ha}^{-1}\right)$ and $S\left(19.4 \mathrm{~kg} \mathrm{ha}^{-1}\right)$ were recorded with $120 \mathrm{~kg} \mathrm{~N} \mathrm{ha}^{-1}$ and $30 \mathrm{~kg} \mathrm{Sha}^{-1}$, respectively.
\end{abstract}

Keywords: Nitrogen, sulphur, quality, nutrient uptake, yield, wheat

\section{INTRODUCTION}

Wheat (Triticum aestivum $\mathrm{L}$ ) is the most important staple food grain in Indian diet and main source of protein and calories for a large section of population. There is a decline in productivity of wheat as a result of degradation of the soil and water resources and inadequate nutrient management. Optimum nutrition is required for getting maximum yield and good quality of produce (Pandey et al. 2020). Nitrogen is one of the major deficient plant nutrients particularly in light textured soils of semi-arid region of western Uttar Pradesh. An optimum supply of nitrogen is important for vigorous vegetative growth, chlorophyll formation and carbolydrate utilization. But nitrogen use efficiency in cereal is quite low. The crop removal of nitrogen or apparent recovery of applied nitrogen is often used as one of the important criteria to judge the crop response to nitrogen application. Application of nitrogen has shown promising results not only sustaining the production but also increased the quality of produce (Singh and Singh. 2017). The management of use efficiency of fertilizer nitrogen applied seems to be crucial factors in increasing productivity of wheat. There isa stagnation in productivity of wheat because sulphur deficiency is very common in alluvial soil of Agra (Singh, 2015). Sulphur deficiency in crop plants has been recognized as a limiting factor not only for crop production but also for poor quality of products, because sulphur is a constituent of several essential compounds such as cysteine, methionme cystine, coenzymes and sulfolipids etc. It has a role to play in increasing chlorophyll formation and aiding photosynthesis. However, studies investigating the impact of nitrogen and sulphur fertilization on yield of wheat remain scarce in Agra region. The present investigation was, therefore, planned to study the effect of nitrogen and sulphur on productivity, nutrient uptake and quality of wheat in alluvial soil. 


\section{MATERIALS AND METHODS}

A field experiment was conducted for two consecutive years (2014-16) at farmer field at Panwari village, Agra (U.P.). The experimental site is characterized by semi-arid climate with extreme temperature during summer $\left(45^{\circ}\right.$ to $48^{\circ}$ C) and very low temperature during winter (as low as $2^{0} \mathrm{C}$ ). The average rainfall is about 650 $\mathrm{mm}$, most of which is received from June to September. The soil was sandy loam in texture with alkaline $\mathrm{pH}(8.0)$, low in organic carbon (3.0 $\left.\mathrm{g} \mathrm{kg}^{-1}\right)$. The soil was low in available $\mathrm{N}(175 \mathrm{~kg}$ $\left.\mathrm{ha}^{-1}\right), \mathrm{P}\left(9.5 \mathrm{~kg} \mathrm{ha}^{-1}\right)$, and medium in $\mathrm{K}(125 \mathrm{~kg}$ $\left.\mathrm{ha}^{-1}\right)$. The soil was deficient in available $S(17.8$ $\mathrm{kg} \mathrm{ha}^{-1}$ and DTPA-Zn $\left(0.54 \mathrm{mg} \mathrm{kg}^{-1}\right)$. Wheat (HD 2329) was grown during the rabi season of 2014-15 and 2015-16 with four levels each of $\mathrm{N}$ $\left(0,40,80\right.$ and $\left.120 \mathrm{~kg} \mathrm{ha}^{-1}\right)$ and $S(0,10,20$ and $30 \mathrm{~kg} \mathrm{~S} \mathrm{ha}^{-1}$ ) tested in randomized block design with three replications. Basal application of $60 \mathrm{~kg}$ $\mathrm{P}_{2} \mathrm{O}_{5}$ and $40 \mathrm{~kg} \mathrm{~K}_{2} \mathrm{O}$ ha $^{-1}$ was made through diammoniumphosphate and muriate of potash, respectively. Nitrogen and sulphur were applied as urea and, elemental sulphur, respectively. Full quantity of $\mathrm{P}, \mathrm{K}$ and $\mathrm{S}$ was applied at sowing time. Half of $\mathrm{N}$ was applied at sowing time and another half was applied in two splits, one-half at first irrigation and the other at tillering stage. The wheat (HD 2329) was sown at the rate of $100 \mathrm{~kg}$ seed $\mathrm{ha}^{-1}$ in second week of November in both the years. All standard packages of practices were adopted for growing a good crop. The crop was harvested in second week of April in both the years.

Plant height and test weight of wheat were recorded at maturity. At harvest grain and straw yields of the crop were recorded. The grain and straw samples were digested in di acid mixture $\left(3: 1\right.$ of $\left.\mathrm{HNO}_{3}: \mathrm{HClO}_{4}\right)$ and analysed for $\mathrm{P}$ by molybdovanadate yellow colour method, $\mathrm{K}$ by flame photometer, sulphur by turbidimetric method. Nitrogen content in grain and straw was determined by modified Kjeldahl' method (Jackson 1973). The uptake of nutrients was computed from their concentrations in grain and straw and respective yields of the crop. Post harvest soil samples collected after two years of experiment were air-dried, ground to pass through $2 \mathrm{~mm}$ sieve and analysed for organic carbon, available N (Subbiah and Asija, 1956), available $P$ (Olsen et al. 1954) and available $S$ (Chesnin and Yien, 1951). The mean data on various parameters obtained from consecutive two years were statistically analysed as per procedure given by Gomez and Gomez (1984). Least significant difference (LSD) values at $\mathrm{P}=$ 0.05 were used to determine the significance of difference between treatment means.

\section{RESULTS AND DISCUSSION}

\section{Growth and yield attributes}

Application of nitrogen significantly increased the plant height over control and tallest plants $(92.1 \mathrm{~cm})$ were recorded under 120 $\mathrm{kg} \mathrm{N} \mathrm{ha}^{-1}$ and minimum plant height $(70.0 \mathrm{~cm})$ at control. Increasing rate of $\mathrm{N}$ from 0 to $120 \mathrm{~kg} \mathrm{~N}$ $\mathrm{ha}^{-1}$ significantly increased the test weight from 35.5 to $40.9 \mathrm{~g}$. on low nitrogen status soil, these significant improvements with increasing levels of $\mathrm{N}$ might be on account of high uptake of required nutrients. The cell division and enlargement also accelerated by ample supply of nitrogen. The present findings are in consonance with those of Kumar et al. (2018) and Singh et al. (2018). Sulphur application significantly improved plant growth in terms of plant height over control. Test weight of wheat showed marked improvement with successive increase in $S$ levels up to $30 \mathrm{~kg} \mathrm{~S} \mathrm{ha-1}$. Significantly taller plants $(90.9 \mathrm{~cm})$ and higher test weight $(39.1 \mathrm{~g})$ were recorded with $30 \mathrm{~kg} \mathrm{~S}$ $\mathrm{ha}^{-1}$. Sulphur is involved in synthesis of $S$ containing amino acid, various enzymatic processes and various oxidation reduction reaction of plant resulting in greater meristamatic activities and apical growth thereby improving overall plant growth (Singh et al. 2020).

\section{Yield}

The grain and straw yield of wheat recorded a significant increase over control with application of graded doses of $\mathrm{N}$ up to $120 \mathrm{~kg} \mathrm{~N} \mathrm{ha}^{-1}$ (Table 1). The application of $120 \mathrm{~kg} \mathrm{~N} \mathrm{ha}^{-1}$ increased the mean grain and straw yield by 44.6 and $42.6 \%$, respectively over control. As grain yield is primarily a function of cumulative effect of yield attributing characters, the higher values of these attributes can be assigned as the most probable reason for significant increase in grain yield. The higher straw yield may be due to improved biomass per plant at successive stages and increase in various morphological 
Table 1: Effect of nitrogen and sulphur on growth, yield and quality of wheat (mean of 2 years)

\begin{tabular}{|c|c|c|c|c|c|c|c|}
\hline \multirow{2}{*}{ Treatment } & \multirow{2}{*}{\begin{tabular}{|c|} 
Plant height \\
(cm)
\end{tabular}} & \multirow{2}{*}{$\begin{array}{c}\text { Test } \\
\text { weight(g) }\end{array}$} & \multicolumn{2}{|c|}{ Yield $\left(\mathrm{t} \mathrm{ha}^{-1}\right)$} & \multicolumn{2}{|c|}{ Protein (\%) } & \multirow{2}{*}{$\begin{array}{l}\text { Protein yield } \\
\left(\mathrm{kg} \mathrm{ha}^{-1}\right)\end{array}$} \\
\hline & & & Grain & Straw & Grain & Straw & \\
\hline \multicolumn{8}{|l|}{ Nitrogen $\left(\mathrm{kg} \mathrm{ha}^{-1}\right)$} \\
\hline 0 & 70.0 & 35.5 & 3.85 & 4.81 & 12.3 & 3.0 & 473.5 \\
\hline 40 & 76.8 & 37.2 & 4.19 & 5.19 & 12.5 & 3.1 & 523.7 \\
\hline 80 & 84.4 & 38.8 & 4.85 & 6.01 & 12.9 & 3.3 & 625.5 \\
\hline 120 & 92.1 & 40.9 & 5.57 & 6.86 & 13.3 & 3.6 & 740.0 \\
\hline$C D(P=0.05)$ & 4.02 & 0.71 & 0.64 & 0.81 & 0.23 & 0.09 & 22.90 \\
\hline \multicolumn{8}{|l|}{ Sulphur $\left(\mathrm{kg} \mathrm{ha}^{-1}\right)$} \\
\hline 0 & 70.5 & 35.7 & 4.08 & 5.06 & 12.4 & 3.1 & 505.9 \\
\hline 10 & 77.1 & 38.0 & 4.44 & 5.51 & 12.6 & 3.2 & 559.4 \\
\hline 20 & 84.8 & 39.1 & 4.80 & 5.95 & 12.8 & 3.3 & 614.4 \\
\hline 30 & 90.9 & 39.6 & 5.13 & 6.36 & 13.1 & 3.4 & 672.0 \\
\hline$C D(P=0.05)$ & 4.02 & 0.71 & 0.64 & 0.81 & 0.23 & 0.09 & 22.90 \\
\hline
\end{tabular}

parameters like plant height, number of tillers etc. Significant improvement in yield owing to $\mathrm{N}$ influenced the grain and straw yield of wheat which increased up to $30 \mathrm{~kg} \mathrm{~S}^{-1}$ (Table 1). The increases in grain and straw yield were from $4.08 \mathrm{t} \mathrm{ha}^{-1}$ to $5.13 \mathrm{t} \mathrm{ha} \mathrm{h}^{-1}$ and $5.06 \mathrm{t}$ to $6.36 \mathrm{t} \mathrm{ha}^{-1}$, respectively as the doses of $S$ increased from 0 to $30 \mathrm{~kg} \mathrm{~S} \mathrm{ha}^{-1}$.

The effect of $S$ fertilization appears to be due to vigorous growth of plant as its presence in plant system suggests greater availability of metabolites and nutrients synchronized to demand for growth and development of each application was also reported by Kumar et al. (2018). Application of sulphur significantly reproductive structure. The significant interaction effect between $\mathrm{N}$ and $\mathrm{S}$ revealed that the addition of $\mathrm{N}$ increased the grain and straw yield of wheal at all the levels of sulphur (Table 2). The effect of $\mathrm{N}$ was more effective in increasing the yields than that of sulphur. Application of 120 $\mathrm{kg} \mathrm{N} \mathrm{ha}^{-1}$ along with $30 \mathrm{~kg} \mathrm{~S} \mathrm{ha}^{-1}$ produced the maximum grain $\left(6.19 \mathrm{tha}^{-1}\right)$ and straw $\left(7.61 \mathrm{th}^{-1}\right)$ yields of wheat. On the other hand, minimum yields of wheat were recorded without nitrogen and sulphur (control) treatment.

Table 2: Interactive effect of $\mathrm{N}$ and $\mathrm{S}$ levels on yields of wheat (means of 2 years)

\begin{tabular}{|c|cc|c|c|c|c|c|c|}
\hline \multirow{2}{*}{ Sulphur $\left(\mathrm{kg} \mathrm{ha}^{-1}\right)$} & \multicolumn{4}{|c|}{ Nitrogen $\left(\mathrm{kg} \mathrm{ha}^{-1}\right)$} & \multicolumn{4}{c|}{ Nitrogen $\left(\mathrm{kg} \mathrm{ha}^{-1}\right)$} \\
\cline { 2 - 8 } & 0 & 40 & 80 & 120 & 0 & 40 & 80 & 120 \\
0 & \multicolumn{4}{c}{ Grain Yield $\left(\mathrm{t} \mathrm{ha}^{-1}\right)$} \\
10 & 3.36 & 3.79 & 4.37 & 4.81 & 4.20 & 4.70 & 5.42 & 5.92 \\
20 & 3.68 & 4.09 & 4.63 & 5.39 & 4.60 & 5.07 & 5.74 & 6.63 \\
30 & 4.01 & 4.26 & 5.03 & 5.91 & 5.01 & 5.28 & 6.24 & 7.27 \\
$\mathrm{CD}(\mathrm{P}=0.05)$ & 4.36 & 4.61 & 5.37 & 6.19 & 5.45 & 5.72 & 6.66 & 7.61 \\
\hline
\end{tabular}

\section{Protein}

The higher protein content in grain $(13.3 \%)$ and straw (3.6\%) was obtained with 120 $\mathrm{kg} \mathrm{N} \mathrm{ha}^{-1}$ which was significantly higher than that of control. Significant increase in grain $\mathrm{N}$ content with increasing levels of nitrogen could be attributed to more nitrogen uptake by the crop and more translocation of $\mathrm{N}$ to grain. Nitrogen, being the precursor of protein, increased grain protein content accordingly. Similar results were reported by Singh and Singh (2017). Increasing levels of $\mathrm{N}$ from 0 to $120 \mathrm{~kg} \mathrm{~N}^{-1}$ increased the protein yield significantly over control. The maximum value of protein yield $\left(740.0 \mathrm{~kg} \mathrm{ha}^{-1}\right)$ was accrued with $120 \mathrm{~kg} \mathrm{~N} \mathrm{ha}^{-1}$. The increase in protein yield may be attributed to increased grain yield and improvement in protein content due to $\mathrm{N}$ application (Singh and Singh 2013). Protein content in wheat grain and straw was markedly increased due to sulphur application (Table 1). The magnitude of increase in protein content due to sulphur application varied from 12.4 to $13.1 \%$ in grain and 3.1 to $3.4 \%$ in straw. The 
maximum values of protein content in grain and stover (13.1 and $3.4 \%$ ) were recorded with $30 \mathrm{~kg}$ $S \mathrm{ha}^{-1}$. This increase in protein content with $\mathrm{S}$ application could be due to the fact that $S$ is an integral part of $S$ containing amino acids namely methonine, cystine and cystein. Similar results were reported by Singh and Singh(2020). Protein yield in wheat grain increased significantly with increasing levels of applied sulphur over control. Application of $30 \mathrm{~kg} \mathrm{~S}^{-1}$ recorded the highest yield of protein $(672.0 \mathrm{~kg}$ $\mathrm{ha}^{-1}$ ) and may be attributed to higher grain yield as well as increased protein content (Singh 2018).

\section{Uptake of nutrients}

Nitrogen uptake by wheat grain and straw increased significantly with $\mathrm{N}$ application in soil (Table 3 ). The maximum $\mathrm{N}$ uptake by grain and straw of 118.6 and $39.0 \mathrm{~kg} \mathrm{ha}^{-1}$, respectively was recorded with $120 \mathrm{~kg} \mathrm{~N}^{-1}$ and the minimum of 75.8 and $23.0 \mathrm{~kg} \mathrm{ha}^{-1}$ in control. Application of $120 \mathrm{~kg} \mathrm{~N} \mathrm{ha}^{-1}$ registered 56.4 and $69.5 \%$ higher uptake of nitrogen in grain and straw, respectively over control. Significant increase in $\mathrm{N}$ uptake might be due to the influence of increased yield and $\mathrm{N}$ content in crop with its application to soil. The results are in agreement with the findings of Singh and Singh (2017). Nitrogen uptake by wheat grain and straw increased significantly with increasing levels of $S$ and the highest $\mathrm{N}$ uptake was observed with 30 $\mathrm{kg} \mathrm{S} \mathrm{ha}^{-1}$ i.e. 108.7 and $35.0 \mathrm{~kg} \mathrm{ha}^{-1}$ and lowest in the control i.e. 81.2 and $25.3 \mathrm{~kg} \mathrm{ha}^{-1}$. Higher values of $\mathrm{N}$ uptake with increasing levels of $\mathrm{S}$ are apparently the result of favourable effect of the sulphur on $\mathrm{N}$ content coupled with grain and straw yield. Similar results were also reported by Singh and Singh (2020).

Table 3: Effect of nitrogen and sulphur on uptake of nutrients ( $\left.\mathrm{kg} \mathrm{ha}^{-1}\right)$ in wheat (mean of 2 years)

\begin{tabular}{|c|c|c|c|c|c|c|c|c|}
\hline \multirow{2}{*}{ Treatment } & \multicolumn{2}{|c|}{ Nitrogen } & \multicolumn{2}{|c|}{ Phosphorus } & \multicolumn{2}{|c|}{ Potassium } & \multicolumn{2}{|c|}{ Sulphur } \\
\hline & Grain & Straw & Grain & Straw & Grain & Straw & Grain & Straw \\
\hline \multicolumn{9}{|l|}{ Nitrogen $\left(\mathrm{kg} \mathrm{ha}^{-1}\right)$} \\
\hline (1) & 75.8 & 23.0 & 6.9 & 4.3 & 19.2 & 90.4 & 8.0 & 5.7 \\
\hline 40 & 84.2 & 26.4 & 8.0 & 5.1 & 21.7 & 98.6 & 9.6 & 7.2 \\
\hline 80 & 100.3 & 32.4 & 10.6 & 7.2 & 26.1 & 115.3 & 12.1 & 9.0 \\
\hline 120 & 118.6 & 39.0 & 13.9 & 8.9 & 31.0 & 133.7 & 14.4 & 11.6 \\
\hline$C D(P=0.05)$ & 5.95 & 2.82 & 1.50 & 0.59 & 2.10 & 6.18 & 0.86 & 0.62 \\
\hline \multicolumn{9}{|l|}{ Sulphur $\left(\mathrm{kg} \mathrm{ha}^{-1}\right)$} \\
\hline 0 & 81.2 & 25.3 & 7.7 & 5.0 & 20.8 & 96.5 & 8.1 & 5.0 \\
\hline 10 & 90.1 & 28.6 & 8.8 & 5.5 & 23.0 & 104.6 & 10.2 & 7.7 \\
\hline 20 & 98.9 & 31.6 & 10.5 & 7.2 & 25.9 & 114.2 & 12.0 & 9.5 \\
\hline 30 & 108.7 & 35.0 & 11.7 & 7.8 & 28.3 & 122.7 & 13.8 & 11.4 \\
\hline$C D(P=0.05)$ & 5.95 & 2.82 & 1.50 & 0.59 & 2.10 & 6.18 & 0.86 & 0.62 \\
\hline
\end{tabular}

Application of $\mathrm{N}$ resulted in significant increase in $\mathrm{P}$ uptake by the wheat crop over the control. The maximum uptake of $P$ by grain and straw was recorded when the crop was fertilized with $120 \mathrm{~N} \mathrm{ha}^{-1}$ and it was found significantly superior to lower levels of $\mathrm{N}$. This could be ascribed to the increased grain and straw yield together with higher $\mathrm{P}$ content. The results confirm the findings of Singh (2019). The uptake of $P$ by wheat grain and straw increased significantly with $S$ application over control. The mean uptake of $P$ in wheat grain and straw increased from 7.7 to $11.7 \mathrm{~kg} \mathrm{ha}^{-1}$ and 5.0 to 7.8 $\mathrm{kg} \mathrm{ha}^{-1}$ with $30 \mathrm{~kg} \mathrm{~S} \mathrm{ha}^{-1}$, respectively. The magnitude increase in $P$ uptake with $30 \mathrm{~kg} \mathrm{~S} \mathrm{ha}^{-1}$ was 51.9 and $56.0 \%$ in grain and stover, respectively over the control. The higher $P$ removal due to $S$ application could be attributed to the priming effect caused by higher crop growth and consequently higher removal due to balanced fertilization. The results corroborate with the findings of Singh and Singh (2020).Significant improvement in K uptake by wheat grain and straw was observed with each increment of $\mathrm{N}$ applied up to $120 \mathrm{~kg} \mathrm{~N} \mathrm{ha}^{-1}$. The uptake by grain and straw increased from 19.2 to $31.0 \mathrm{~kg} \mathrm{ha}^{-1}$ and from 90.4 to $133.7 \mathrm{~kg} \mathrm{ha}^{-1}$, respectively due to the application of $120 \mathrm{~kg} \mathrm{~N}$ $\mathrm{ha}^{-1}$. The increase in $\mathrm{K}$ uptake by the crop may be attributed to the improvement in available $\mathrm{K}$ status in soil due to nitrogen application (Singh and Singh 2017). The uptake of $\mathrm{K}$ by wheat crop improved significantly with sulphur addition over control. Sulphur addition increased $\mathrm{K}$ uptake bygrain and straw of wheat from 20.8 to $28.3 \mathrm{~kg}$ $\mathrm{ha}^{-1}$ and 96.5 to $122.7 \mathrm{~kg} \mathrm{ha}^{-1}$ as the dose of Sincreased from 0 to $30 \mathrm{~kg} \mathrm{ha}^{-1}$. Higher uptake ofK might be due to higher grain and straw yield. 
Similar results were reported by Singh et al. (2020) in pearl millet.A marked increase in $S$ uptake by grain $\left(14.4 \mathrm{~kg} \mathrm{ha}^{-1}\right)$ and straw $(11.6 \mathrm{~kg}$ $\mathrm{ha}^{-1}$ ) was recorded with the application of $120 \mathrm{~kg}$ $\mathrm{N}$ ha $^{-1}$. Since, the $\mathrm{S}$ uptake is a function of its content in crop plant and yield of crop, the increase in these parameters due to $\mathrm{N}$ application led to an increased uptake of sulphur by the crop. These results are in conformity with the findings of Khriezovono Rino et al. (2020). Application of $30 \mathrm{~kg} \mathrm{~S}^{-1}$ recorded significantly highest uptake of sulphur by the crop over other levels of $S$ and control. This might be attributed to increased $S$ availability from applied $S$ with a concomitant increase in $S$ concentration and grain and straw yield of wheat. The results corroborate with the findings of Singh and Singh (2020).

\section{Soil fertility}

Application of $\mathrm{N}$ significant increased the organic carbon content in post harvest soil over control. The highest organic carbon in soil $4.4 \mathrm{~g}$ $\mathrm{kg}^{-1}$ ) was recorded with $120 \mathrm{~kg} \mathrm{~N} \mathrm{ha}^{-1}$ and lowest $\left(3.2 \mathrm{~g} \mathrm{~kg}^{-1}\right)$ in control. Beneficial effect of $\mathrm{N}$ application on organic carbon was related to the incorporation of organic material in the form of roots and shoot in soil and better regulation of organic carbon dynamics in soil. Similar results were reported by Singh (2019). .Application of sulphur significantly increased the organic carbon content in post harvest soil over control. The organic carbon content in soil varied from 3.6 to $4.1 \mathrm{~g} \mathrm{~kg}^{-1}$ (Table 4). Application of $30 \mathrm{~kg} \mathrm{~S}$ $\mathrm{ha}^{-1}$ showed the maximum content of $4.1 \mathrm{~g} \mathrm{~kg}^{-1}$ organic carbon and the minimum content of 3.6 $\mathrm{g} \mathrm{kg}^{-1}$ being in control. The increase in organic carbon content might be due to addition of $S$ resulting in improvement in root and shoot growth and thus higher production of biomass might have increased the organic carbon content. Results corroborate the finding of Singh et al. (2020).

Table 4: Effect of various treatments on status of organic carbon and available nutrients in post harvest soil

\begin{tabular}{c|c|c|c|c|}
\hline Treatment & Org. Carbon $\left(\mathrm{g} \mathrm{kg}^{-1}\right)$ & Nitrogen $\left(\mathrm{kg} \mathrm{ha}^{-1}\right)$ & Phosphorus $\left(\mathrm{kg} \mathrm{ha}^{-1}\right)$ & Sulphur $\left(\mathrm{kg} \mathrm{ha}^{-1}\right)$ \\
\hline Nitrogen $\left(\mathrm{kg} \mathrm{ha}^{-1}\right)$ & & & & \\
0 & 3.2 & 166.2 & 9.0 & 14.5 \\
40 & 3.7 & 180.4 & 10.3 & 15.0 \\
80 & 3.9 & 203.0 & 11.1 & 16.5 \\
120 & 4.4 & 222.5 & 14.7 & 0.8 \\
$\mathrm{CD}(\mathrm{P}=0.05)$ & 0.05 & 12.1 & 0.13 & \\
Sulphur (kg ha & & & & 13.4 \\
0 & & 180.6 & 9.5 & 14.0 \\
10 & 3.6 & 188.5 & 10.0 & 17.0 \\
20 & 3.7 & 196.6 & 12.0 & 19.4 \\
30 & 3.8 & 206.5 & 13.6 & 0.21 \\
\hline
\end{tabular}

Application of varying levels of $\mathrm{N}$ significantly influenced the available nitrogen status of soil (Table 4). It varied from 166.2 to $222.5 \mathrm{~kg} \mathrm{ha}^{-1}$ in control and $120 \mathrm{~kg} \mathrm{~N} \mathrm{ha}^{-1}$, respectively. The lowest value of available $\mathrm{N}$ was statistically inferior to lower levels of $\mathrm{N}$. The lower content in control plots is a result of mining pf available $\mathrm{N}$ by the crop. The significant increase in available $\mathrm{N}$ content in post harvest soil was corded with $30 \mathrm{~kg} \mathrm{~S} \mathrm{ha}^{-1}$ over control. Available $\mathrm{N}$ content in soil varied from $180.6 \mathrm{~kg}$ $\mathrm{ha}^{-1}$ in control to $206.5 \mathrm{~kg} \mathrm{ha}^{-1}$ with $30 \mathrm{~kg} \mathrm{~S}^{-1}$. Increase in $\mathrm{N}$ concentration in soil may be due to stimulating activity of microorganisms leading to mineralization of $\mathrm{N}$ at increased organic carbon content. Increase in $\mathrm{N}$ availability as a result of $\mathrm{S}$ application has been reported by Singh et al.
(2020). The available $P$ content of the soil varied from $9.0 \mathrm{~kg} \mathrm{ha}^{-1}$ in control to $14.7 \mathrm{~kg} \mathrm{ha}^{-1}$ in plots which had received $120 \mathrm{~kg} \mathrm{~N}^{-1}$. In control plots, the available $P$ decreased to $9.0 \mathrm{~kg} \mathrm{ha}^{-1}$ from the initial value of $9.5 \mathrm{~kg} \mathrm{ha}^{-1}$. The available $\mathrm{P}$ content in post harvest soil ranged from 9.5 to $13.6 \mathrm{~kg} \mathrm{ha}^{-1}$ among the levels of sulphur. The highest available $\mathrm{P}$ content in soil was found under the treatment receiving $30 \mathrm{~kg} \mathrm{~S} \mathrm{ha}^{-1}$ whereas the lowest amount of available $P$ content in soil $\left(9.5 \mathrm{~kg} \mathrm{ha}^{-1}\right)$ was observed in control. The increase in available $\mathrm{P}$ may be attributed to solubilization of native and added sources and mobilizing soil $P$ in available form and their available $\mathrm{P}$ increased. Similar results were observed by Singh et al. (2020). The available $S$ content in soil at the harvest of wheat 
crop ranged from 14.5 to $17.8 \mathrm{~kg} \mathrm{ha}^{-1}$. The highest content of available sulphur was found with $120 \mathrm{~kg} \mathrm{~N} \mathrm{ha}^{-1}$. On the other hand, the lowest amount of available $S$ was found in control (14.5 $\left.\mathrm{kg} \mathrm{ha}^{-1}\right)$. Available $S$ increased significantly with increasing levels of $S$ and maximum value of $19.4 \mathrm{~kg} \mathrm{ha}^{-1}$ was recorded with $30 \mathrm{~kg} \mathrm{~S} \mathrm{ha}^{-1}$. Application of $30 \mathrm{~kg} \mathrm{~S}$ ha $^{-1}$ resulted in an improvement of $6 \mathrm{~kg} \mathrm{~S}^{-1}$ over control while it was depleted under control. This improvement may be attributed to relatively less absorption of sulphur by crop than its supply while depletion may be due to removal of sulphur from the soil

\section{REFERENCE}

Chesnin, L. and Yien, C.H. (1951) Turbidmetric determination of available sulphate.Proceeding of Soil Science Society of America 15: 149-151.

Jackson, M.L. (1973) Soil Chemical Analysis. Prentice Hall of India Private Limited, New Delhi

Khriezovono Rino, Singh, P.L., Singh, A.P. and Depika, N. (2020) Effect of plant population and source of nitrogen on growth and yield of baby corn (Zea mays L.). Annals of Plant and Soil Research 22(2): 206-209.

Kumar, M., Singh, L. and Gupta, D.D. (2018) Productivity and profitability of barley (Hordeum vulgare) as affected by nitrogen levels and varieties under rain fed condition. Annals of Plant and Soil Research 20(4): 375-378.

Olsen, S.R., Cole, C.V., Watanabe, F.S. and Dean, L.A. (1954) Estimation of available phosphorus in soils extraction with sodium bicarbonate. Circ. U.S.Dept. agric. 939.

Pandey, M., Kumar, S. and Singh, U.N. (2020) Effect of integrated nutrient management on productivity of oat (Avena sativa $\mathrm{L}$ ) and soil fertility.Annals of Plant andSoil Research 22 (2):151-155.

Sikarwar, B.P.S., Gupta, D. and Singh, L. (2018) Effect of varying nitrogen levels and varieties on productivity and profitability of wheat (Triticum aestivum) under rainfed condition. Annals of Plant and Soil Research20(1): 58-62.

Singh, D. and Singh, D. (2017) Effect of nitrogen and FYM on yield, quality and uptake of nutrients in wheat (Tridicum aestivum). Annals of Plant and Soil Research 19(2):232-236.

Singh, R., Singh, U.N., Chauhan, T.M. and Singh, V. (2020) Sulphur fertilization for by the crop. Singh et al. (2020) also reported similar results.

From the present investigation, it may be concluded that wheat crop responded significantly to application of $120 \mathrm{~kg} \mathrm{~N} \mathrm{ha}^{-1}$ and $30 \mathrm{~kg} \mathrm{~S} \mathrm{ha}^{-1}$. Thus it is inferred that application of $120 \mathrm{~kg} \mathrm{~N}$ and $30 \mathrm{~kg} \mathrm{~S} \mathrm{ha}^{-1}$ is required for obtaining high productivity and maintaining soil fertility. Application of $\mathrm{N}$ to wheat proved more beneficial than sulphur. The quality and uptake of nutrients also improved significantly with $\mathrm{N}$ and $\mathrm{S}$ application over their respective controls.

enhancing the productivity of pearl millet (Pennisetum glaucum) and soil fertility in alluvial soil.Annals of Plant and Soil Research 22 (1): 96-99.

Singh, S. (2015) Forms of sulphur in relation to soil properties under pearl millet cultivation in soils of Agra region, Uttar Pradesh. Annals of Plant and Soil Research 17(4): 362-365.

Singh, S. (2018) Available nutrients status and response of wheat (Triticum aestivum L.) to sulphur and zinc application in Inceptions of Varanasi. Journal of the Indian Society of Soil Science 66(1): 116-119.

Singh, U.N. and Singh, V. (2020) Effect of sources and levels of sulphur on yield, quality and uptake of nutrients in pearl millet (Pennisetum glaucum) and wheat (Triticum aestivum) grown in sequence on an alluvial soil. Annals of Plant and soil Research 22(3): 234-238.

Singh, V. (2019) Effect of nutrient management on yield, uptake of nutrients and soil fertility under pearl millet (Pennisetum glaucum)wheat (Triticum aestivum) crop sequence. Annals of Plant and Soil Research 21(2): 149-153.

Singh, V., Singh, S.P. Singh, S and Shivay, Y.S. (2013) Growth, yield and nutrient uptake by wheat (Triticum aestivum) as affected by biofertilizers, FYM and nitrogen. Indian Journal of Agricultural Sciences 83 (3): 331-334.

Subbiah, B.V. and Asija, G.L. (1956) Arapid method for the estimation of available nitrogen in soils. Current Science 25: 259260. 